\title{
Prevalence of liver abnormality in early syphilis
}

\author{
S I TERRY, * B HANCHARD, $S$ E H BROOKS, † H MCDONALD, † AND S SIVAł \\ From the Departments of ${ }^{*}$ Medicine and + Pathology, University of the West Indies, Mona, and the \\ ¥Ministry of Health and Environmental Control, Kingston, Jamaica, West Indies
}

SUMMARY Hepatic structure and function of 22 unselected patients with early syphilis was assessed. In $20(91 \%)$ routine hepatic tests or bromsulphalein retention showed mild non-specific abnormalities. Minor changes in hepatic structure were present in $12(55 \%)$, in three of whom intrahepatic spirochaetes were found. The only patient who had hepatomegaly also had splenomegaly. Observed changes in hepatic structure correlated with neither physical signs nor results of biochemical tests. Hepatic changes in early syphilis are common but frequently subclinical.

\section{Introduction}

The liver is said to be the third most common site of involvement in late syphilis. ${ }^{1}$ Whereas amyloid infiltration and macronodular cirrhosis seen in late syphilis may, ${ }^{2}$ or may not $^{3}$ be caused by the spirochaetal infection, other late changes are well described and characteristicl : isolated scars, single or multiple gummata, with or without scars, leading to hepar lobatum were found by Hahn to occur in 5\% of untreated patients. ${ }^{3}$

Little is known of the sequence of changes in the liver from the early stages of involvement to advanced complications, ${ }^{4}$ possibly for the following three reasons. Firstly, percutaneous biopsy of the liver coincided with the introduction of penicillin into clinical practice. Secondly, early syphilis is rarely fatal, and therefore autopsy studies do not exist. Thirdly, in the pre-antibiotic era "acute yellow atrophy" associated with secondary syphilis was probably related to intravenous heavy metal treatment ${ }^{5} 6$ or acute viral hepatitis transmitted by syringe. ${ }^{7}$ Modern detailed data consist of a number of single case reports ${ }^{8-24}$ together with two series of patients, one Hungarian, ${ }^{25-27}$ the other English. ${ }^{28}$ The results of both series may, however, have been biased by the method of selection of patients to be studied.

In order to define accurately the prevalence of hepatic changes in the spirochaetaemic stage of Treponema pallidum infection, we studied hepatic clinicopathology of consecutive patients who had secondary (early) syphilis. The hepatic structural changes have been described in detail elsewhere. ${ }^{29}$

\footnotetext{
Address for reprints: Dr S I Terry, Department of Medicine, University of the West Indies, Mona, Kingston 7, Jamaica, West Indies

Accepted for publication 26 July 1983
}

\section{Patients and methods}

We studied 22 patients with early syphilis attending a dermatovenereology or a general medical clinic in Kingston, Jamaica. All had characteristic mucocutaneous changes and all gave strongly positive results to Venereal Disease Research Laboratory (VDRL) and fluorescent treponemal antibody absorbed (FTA-ABS) serological tests. Spirochaetes were also shown in local lesions in 12 patients. All patients were predominantly black. The only criterion for selection, once the diagnosis had been established, was willingness to cooperate in the study. There were 10 men and 12 women (mean age 25 years) who gave their full informed consent (on two separate occasions) to performance of liver biopsy in addition to haematological and biochemical studies. Two further patients declined to participate in the study and one pregnant woman was excluded; they were not investigated further and were immediately treated with antibiotics.

The following were measured by standard methods: serum bilirubin concentration, serum alanine aminotransferase (ALT, previously SGPT) activity, $\gamma$-glutamyl transferase (GGT) activity, alkaline phosphatase activity, total serum protein concentrations and electrophoretic pattern, and one stage prothrombin time. Alkaline phosphatase fractionation was performed using polyacrylamide gel electrophoresis. Bromsulphalein (BSP) retention at 45 minutes was measured in 20 patients using an intravenous bolus of $5 \mathrm{mg} / \mathrm{kg}$. Liver biopsy specimens were taken under local anaesthesia using a Menghini needle.

For light microscopy, the biopsy specimens were fixed in $10 \%$ formalin and processed by routine methods. Tissue sections were stained by haema- 
toxylin and eosin, periodic acid/Schiff (PAS), Masson's trichrome, Wilder's reticulin and Perls' stains. To identify treponemes Warthin-Starry and Levaditi stains were also used in each case.

Concentrations of serum immunoglobulins G, A, and $M$ were measured by radial immunodiffusion in 21 patients. Hepatitis B surface antigen ( $\mathrm{HBsAg})$ was tested for by counter immunoelectrophoresis.

\section{Results}

\section{CLINICAL FEATURES}

No patient gave a history of ingestion of excessive alcohol, hepatotoxic bush teas, or medicaments. One young woman had an enlarged, slightly firm liver palpable $6 \mathrm{~cm}$ below the right costal margin in the midclavicular line. She also had a soft spleen which was palpable $2 \mathrm{~cm}$ below the left coastal margin in the midclavicular line. No patient was clinically jaundiced.

\section{HISTOPATHOLOGY}

Liver structure on light microscopy was abnormal in 12 patients (fig 1), and normal in 10. In nine there were minor abnormalities characterised by mild to moderate Kupffer cell hyperplasia and focal liver cell necrosis with or without portal tract lymphoid hyperplasia. Three patients showed a well established nonspecific reactive hepatitis with a combination of focal portal tract inflammation, spotty liver cell necrosis, marked Kupffer cell proliferation, and macrovesicular fatty change. Cholestasis was absent in all 22 biopsies.

In three cases, all with abnormal hepatic structure, spirochaetes were shown in liver cells by the WarthinStarry stain (fig 2) but in none by the Levaditi stain. One had minor abnormalities and two had nonspecific reactive hepatitis.

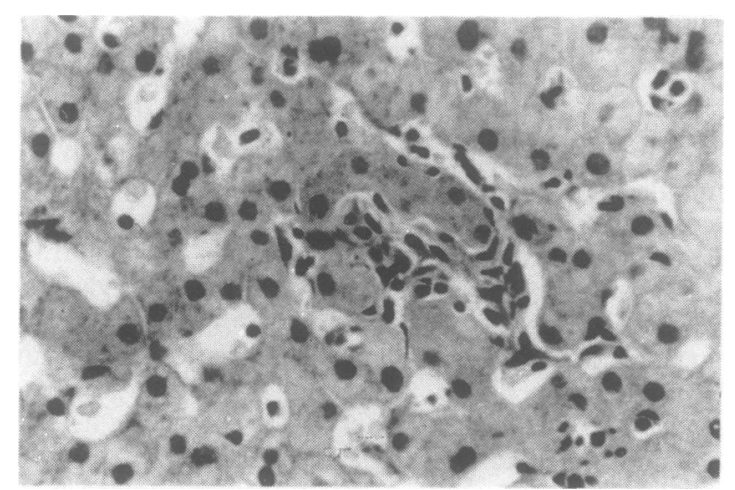

FIG 1 Light micrograph of liver from patient with early syphilis showing diffuse Kupffer cell hyperplasia around degenerating liver cells. Haematoxylin and eosin ( $\times 560)$.

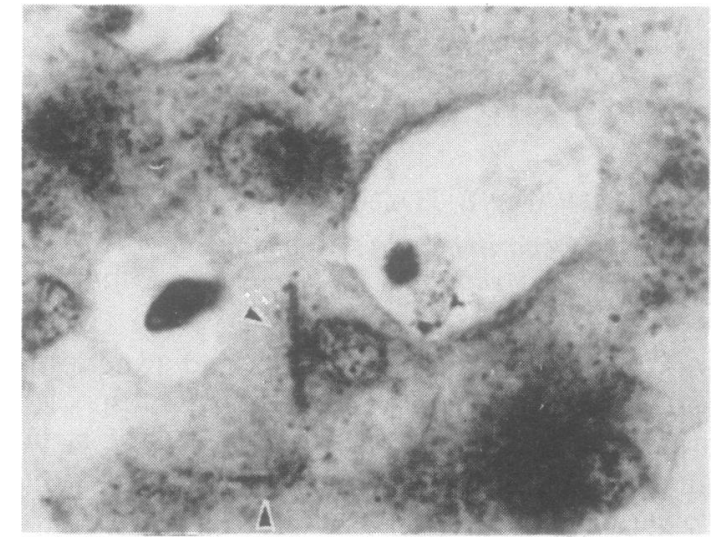

FIG 2 Spirochaetes (arrows) in hepatocytes. WarthinStarry stain $(\times 1000)$.

BIOCHEMICAL INVESTIGATIONS

Changes in liver function were inconsistent. Bromsulphalein retention at 45 minutes was $>5 \%$ in 11 $(55 \%)$ patients. Serum alkaline phosphatase activity was abnormal in $10(45 \%)$; this increased activity was due to the liver isoenzyme in three, bone isoenzyme in one and to both in six patients. Minimal total hyperbilirubinaemia was present in seven $(32 \%)$ patients, of whom three (14\%) had mildly raised ALT activity. No patient had abnormal GGT activity, prothrombin time, or serum albumin concentration.

There was no correlation between any of the liver tests and hepatic morphology. Only two of the 22 patients had totally normal liver tests, one had a normal biopsy and one had minor abnormalities.

Of the 21 patients whose serum immunoglobulin concentrations were measured that of IgA was normal in all except three, who had slightly low concentrations. IgM concentration was raised in one and that of IgG in 15 patients. In general the increase in IgG concentration was large. The laboratory data are summarised in the table. Hepatitis B surface antigen was not detected in the serum of any patient.

\section{Discussion}

The patient population described in this report is different from that found in published reports. Of a total of 43 cases reviewed only seven were women and the mean age of the patients reported was 38 years. The present study includes equal numbers of men and women of a younger age who were predominantly black and who referred themselves for medical care. This may be of importance in view of the suggestion that patients with a rectal primary lesion are more likely to have liver abnormality.20 Because a group of patients has been studied it is also 
TABLE Mean (SD) [and range] of results of liver and immunoglobulin tests related to histological appearances in 22 patients with early syphilis

\begin{tabular}{|c|c|c|c|c|}
\hline \multirow[b]{2}{*}{$\begin{array}{l}\text { Serum concentrations } \\
\text { or activities of: }\end{array}$} & \multicolumn{3}{|c|}{ Histological appearances: } & \multirow[b]{2}{*}{$\begin{array}{l}\text { Normal } \\
\text { range in } \\
\text { Jamaicans }\end{array}$} \\
\hline & $\begin{array}{l}\text { Normal } \\
(n=10)\end{array}$ & $\begin{array}{l}\text { Minor } \\
\text { abnormalities } \\
(n=9)\end{array}$ & $\begin{array}{l}\text { Non-specific } \\
\text { reactive } \\
\text { hepatitis }(n=3)\end{array}$ & \\
\hline $\begin{array}{l}\text { Total bilirubin ( } \mu \mathrm{mol} / \mathrm{l}) \\
\text { Range }\end{array}$ & $\begin{array}{l}15 \cdot 4(8 \cdot 6) \\
{[5 \cdot 1-27 \cdot 4]}\end{array}$ & $\begin{array}{l}13 \cdot 7(12) \\
{[1 \cdot 7-30 \cdot 8]}\end{array}$ & $\begin{array}{l}13 \cdot 7(3 \cdot 4) \\
{[8 \cdot 6-15 \cdot 4]}\end{array}$ & {$[1 \cdot 7-17 \cdot 1]$} \\
\hline $\begin{array}{c}\mathrm{ALT}(\mathrm{IU} / \mathrm{l}) \\
\text { Range }\end{array}$ & $\begin{array}{l}7(5) \\
{[2-19]}\end{array}$ & $\begin{array}{l}11(8) \\
{[4-26]}\end{array}$ & $\begin{array}{l}8(1) \\
{[7-9]}\end{array}$ & {$[2-15]$} \\
\hline $\begin{array}{l}\text { Alkaline phosphatase (IU/l) } \\
\text { Range }\end{array}$ & $\begin{array}{l}112(58) \\
{[49-196]}\end{array}$ & $\begin{array}{l}103(49) \\
{[49-217]}\end{array}$ & $\begin{array}{l}82(51) \\
{[28-140]}\end{array}$ & {$[15-90]$} \\
\hline $\begin{array}{c}\text { GGT (IU/l) } \\
\text { Range }\end{array}$ & $\begin{array}{l}14(5) \\
{[9-21]}\end{array}$ & $\begin{array}{l}13(5) \\
{[6-20]}\end{array}$ & $\begin{array}{l}8(6) \\
{[3-14]}\end{array}$ & $\begin{array}{l}{[<20 \text { in women, }} \\
<30 \text { in men] }\end{array}$ \\
\hline $\begin{array}{l}\text { BSP retention at } 45 \min (\%) \\
\text { Range }\end{array}$ & $\begin{array}{l}9(4)^{* *} \\
{[3-13]}\end{array}$ & $\begin{array}{l}5(3) \\
{[1-8]}\end{array}$ & $\begin{array}{l}6(5) \\
{[3-12]}\end{array}$ & {$[<5]$} \\
\hline $\begin{array}{l}\text { Albumin }(g / l) \\
\text { Range }\end{array}$ & $\begin{array}{l}43(4) \\
{[37-48]}\end{array}$ & $\begin{array}{l}42(3) \\
{[35-45]}\end{array}$ & $\begin{array}{l}39(2) \\
{[37-41]}\end{array}$ & {$[35-55]$} \\
\hline$\underset{\text { Range }}{\text { IgG }}$ & $\begin{array}{l}26 \cdot 8(13 \cdot 1)^{*} \\
{[9-40]}\end{array}$ & $\begin{array}{l}32 \cdot 2(12 \cdot 1) \\
{[11-40]}\end{array}$ & $\begin{array}{l}25 \cdot 6(12 \cdot 7) \\
{[15-40]}\end{array}$ & {$[10-20]$} \\
\hline $\begin{array}{c}\text { IgA ( } \mu \mathrm{g} / \mathrm{l}) \\
\text { Range }\end{array}$ & $\begin{array}{l}2 \cdot 9(1)^{*} \\
{[1 \cdot 3-3 \cdot 8]}\end{array}$ & $\begin{array}{l}2 \cdot 2(1 \cdot 1) \\
{[0 \cdot 5-3 \cdot 9]}\end{array}$ & $\begin{array}{l}2 \cdot 2(0 \cdot 9) \\
{[1 \cdot 6-3 \cdot 3]}\end{array}$ & {$[1 \cdot 5-4 \cdot 5]$} \\
\hline $\begin{array}{r}\text { IgM } \underset{\text { Range }}{(\mu g / 1)} \\
\text { Ran }\end{array}$ & $\begin{array}{l}1 \cdot 1(0 \cdot 6)^{*} \\
{[0 \cdot 4-2 \cdot 4]}\end{array}$ & $\begin{array}{l}1 \cdot 5(0 \cdot 6) \\
{[0 \cdot 8-3 \cdot 5]}\end{array}$ & $\begin{array}{l}1 \cdot 6(1 \cdot 1) \\
{[0 \cdot 9-2 \cdot 8]}\end{array}$ & {$[0 \cdot 8-3]$} \\
\hline
\end{tabular}

Conversion: SI to traditional units-serum bilirubin: $1 \mu \mathrm{mol} / \mathrm{l} \approx 17 \cdot 1 \mathrm{mg} / \mathrm{dl}$. ALT = alanine aminotransferase;

$G G T=\gamma$-glutamyltransferase; $B S P=$ bromsulphalein; $*$ = test not performed in individual case(s).

possible to report those with no histological abnormality (10), as well as those with minor abnormalities (9), and non-specific reactive hepatitis (3). Because of the probable bias towards reporting more severe lesions as case reports, a review of published reports describing hepatic structure on light microscopy shows one with normal structure, 18 with minor abnormalities, and 21 with hepatitis. (In one series a liver biopsy was not performed in three of the nine patients described. ${ }^{28}$ ) Despite the less pronounced hepatic structural changes in the 22 Jamaican patients, spirochaetes were found in the liver biopsies of three. Spirochaetes have occasionally been found in the liver in secondary syphilis, ${ }^{814} 23-2532$ but their presence has not correlated with any particular histopathological change.

It has been thought that hepatomegaly is an essential feature of the liver in secondary syphilis. ${ }^{31} \mathrm{We}$ found this not to be so and our negative finding is supported by others. ${ }^{131519212324}$ Of the 43 cases reported fully in published reports in the past 39 years, 27 had hepatomegaly but 17 of these were from a Hungarian series in which hepatomegaly seems to have been one of the criteria for inclusion in the study. ${ }^{25} 26$ Splenomegaly is even less common. One of our patients had this sign, while there were eight others noted in published reports. 14-16 192025 The presence or absence of hepato(spleno)megaly seems to correlate poorly with the hepatic structural changes observed. Our patient with hepatomegaly had minor abnormalities on light microscopy. The only other patient with normal hepatic structure reported in published reports also had hepatomegaly. ${ }^{25} 26$ The third allegedly important physical sign, jaundice or "benign icterus" described by Gubler, ${ }^{30}$ occurred in none of our cases. Seven cases with jaundice are documented. ${ }^{8} 91114151820$

As may have been predicted, in the spirochaetaemic stage of the infection the prevalence of abnormal liver tests was high. We found that $91 \%$ had abnormal results to at least one test of liver function, and that the test of bromsulphalein retention was the most sensitive (55\% patients were abnormal). Perhaps because of the more pronounced hepatic structural changes reported, the most sensitive test found on review of published reports seemed to be that for serum alanine aminotransferase (serum ALT, old abbreviation SGPT) activity, which gave abnormal results in $73 \%$ ( 31 of 41$)$ of cases. This could not be confirmed as serum ALT activity was abnormal in only $14 \%$ ( 3 of 22 ) of our cases and we did not measure serum aspartate transferase (serum AST, old abbreviation SGOT) activity. Some authors have suggested, on the basis of observed cholestasis in their patients, that raised serum alkaline phosphatase activity is the most important measurement in predicting hepatic abnormality. In this study we found that $45 \%$ had abnormal serum alkaline phosphatase activity, and published reports show 26 of $42(60 \%)$. Raised serum alkaline 
phosphatase activity should be interpreted with care because periostitis, or more severe bony lesion, ${ }^{33}$ or both ${ }^{10} 12$ may be seen in secondary syphilis. Despite the demonstration of the bile ductular damage, the increase in total alkaline phosphatase activity seen in $10(45 \%)$ of our patients reflected increased bone isoenzyme in seven $(32 \%)$, with or without increased hepatic isoenzyme. No patient in this series was found to have microscopic cholestasis on liver biopsy and none had raised serum GGT activity.

One final difference between this and the Hungarian series is that the Jamaican patients appear to have been examined at a later stage, since there was only one patient with raised serum IgM concentrations and 15 of the remainder had raised IgG concentrations, whereas Fehér and his colleagues ${ }^{25}$ described a rise in concentration of serum immunoglobulins of the IgM class. ${ }^{25}$ Nevertheless, the hepatic structural changes observed independently are very similar to ours, which suggests that the structural abnormalities do not necessarily progress during the early stage of infection.

The abnormalities of liver structure and function reported by other workers may have had nothing to do with the spirochaetal infection ${ }^{22} 23$ and may have been due to coincidental viral hepatitis, ${ }^{44}$ a sexually transmissible disease, ${ }^{35}$ alcoholic hepatitis, ${ }^{33}$ or diabetes mellitus. ${ }^{9}$ The changes of hepatic structure that are described in this report are similar to those seen in other infections and are non-specific in the early stages of syphilis; they are probably a result of the spirochaetaemia. Progression to gummata in tertiary syphilis is presumably related to endarteritis, a feature not seen in the present series. Most importantly, no changes suggested that secondary syphilis predisposes to cirrhosis.

This study shows that there were morphological changes in the liver in about half of a group of patients with early syphilis, but the changes were not specific enough to warrant the label syphilitic hepatitis. ${ }^{25-27}$

We thank Dr E Braithwaite and colleagues at the comprehensive clinic and the Kingston Public Hospital for their help and encouragement, Drs $O$ James and W Wilson for performing the serum immunoglobulin assays, $\operatorname{Dr} M \mathrm{M}$ Kaplan of Boston for assistance with alkaline phosphatase fractionation and Mrs Y Piper for secretarial assistance. Some of the data included in this report form part of the MD thesis (University of London) of S Siva.

Presented in part at the 5th Asian Pacific Congress of Gastroenterology, Singapore, May 1976.

\section{References}

1. Lichtman SS. Specific infections of the liver. In: Diseases of the liver, gall-bladder and bile ducts. London: Henry Kimpton, 1953: 1043-68.
2. Karmi G, Thirkettle JL, Read AEA. The association of syphilis with hepatic cirrhosis: a report of six cases and a review of the literature. Postgrad Med J 1969; 45:675-9.

3. Hahn RD. Syphilis of the liver. American Journal of Syphilis, Gonorrhea, and Venereal Disease 1943;27:529-62.

4. Sherlock S. The liver in secondary (early) syphilis. $N$ Engl $J$ Med 1971;284: 1437-8.

5. Leonard MF. Acute yellow atrophy of the liver in early syphilis. Am J Med Sci 1944; 208:461-70.

6. Wile UJ. The treatment of the syphilitic liver and the heart: a therapeutic paradox. Am J Med Sci 1922;164:415-28.

7. Dible JH, McMichael J. The pathology of arsenotherapy jaundice. Br J Vener Dis 1943; 19: 102-8.

8. Baker AL, Kaplan MM, Wolfe HJ, McGowan JA. Liver disease associated with early syphilis. N Engl J Med 1971;284: 1422-3.

9. Bhowmick BK, Simpson B, Way SPB. Secondary syphilis presenting with jaundice. Postgrad Med J 1975;51:412-6.

10. Hjort M, Olsson R, Smith U, Settergren L. Hepatitis in secondary syphilis. Scand J Infec Dis 1977; 9:59-61.

11. Lee RV, Thornton GF, Conn HO. Liver disease associated with early syphilis. $N$ Engl J Med 1971;284:1423-5.

12. Longstreth $\mathbf{P}$, Hoke AW, McElroy C. Hepatitis and bone destruction as uncommon manifestations of early syphilis. Arch Dermatol 1976; 112:1451-4.

13. McCracken JD, Hall WH, Pierce HI. Nephrotic syndrome and acute hepatitis in secondary syphilis. Milit Med 1969; 134: 682-6.

14. Rajam RV, Rangiah PN. Early syphilitic hepatitis. Ind J Vener Dis and Dermatol 1954; 20:83-94.

15. Sarkany I. Pruritus and cholestatic jaundice due to secondary syphilis. Proc Roy Soc Med 1973; 66:237-8.

16. Sewell J, Ahmed MA. Secondary syphilis and hepatitis. $\mathrm{Br}$ Med J 1975;3:42.

17. Sobel HJ, Wolf EH, Passaic NJ. Liver involvement in early syphilis. Archives of Pathology 1972; 93:565-8.

18. Young E, Bahr G, Waye JD. The Jarisch-Herxheimer reaction in syphilitic hepatitis. Am J Gastroenterol 1974;61:476-7.

19. Zellman HE, Norcross JW. Early syphilitic hepatitis. Lahey Clinic Foundation Bulletin 1967; 16:255-9.

20. Haburchak DR, Davidson H. Anorectal lesions and syphilitic hepatitis. West J Med 1978; 128:64-7.

21. Campisi D, Whitcomb C. Liver disease in early syphilis. Arch Intern Med 1979; 139:365-6.

22. Morrison EB, Norman DA, Wingo CS, Henrich WL. Simultaneous hepatic and renal involvement in acute syphilis. Dig Dis Sci 1980; 25: 875-8.

23. Romeu J, Rybak B, Dave P, Coven R. Spirochetal vasculitis and bile ductular damage in early hepatic syphilis. $A m J$ Gastroenterol 1980; 74:352-4.

24. Keisler DS, Starke W, Looney DJ, Mark WW. Early syphilis with liver involvement. JAMA 1982; 247:1999-2000.

25. Fehér J, Somogyi T, Timmer M, Jósza L. Early syphilitic hepatitis. Lancet 1975; ii: 896-9.

26. Fehér J, Somogyi T, Timmer M, Jósza L. Syphilitic hepatitis: clinical, immunological and morphological aspects. Acta Med Acad Sci Hung 1975;32:155-61.

27. Josza L, Timmer M, Somogyi T, Fehér J. Hepatitis syphilitica: a clinico-pathological study of 25 cases. Acta Hepatogastroenterol (Stuttg) 1977; 24:344-7.

28. Pareek SS. Liver involvement in secondary syphilis. Dig Dis Sci 1979;24:41-3.

29. Hanchard B, Brooks SEH, Terry SI. Pathology of the liver in early syphilis. West Indian Med J 1978;27:91-5.

30. Gubler A. Mémoire sur l'ictère qui accompagne quelquefois les éruptions syphilitiques précoces. C R Soc Biol (Paris) 1853;5: 235-69.

31. Stokes JH, King AD. Syphilis of the liver and spleen. In: Stokes JH ed. Modern Clinical Syphilology. Second edition. Philadelphia: WB Saunders, 1934:965-1017.

32. Warthin AS. The new pathology of syphilis. American Journal of Syphilis, Gonorrhea, and Venereal Disease 1918; 2:413-52.

33. Parker JDJ. Uncommon complications of early syphilis. Br J Vener Dis 1972; 48:32-6.

34. Terry SI, Siva S. Hepatitis B antigen and serological evidence of syphilis. Lancet 1975; ii: 871.

35. Jeffries DJ, James WH, Jefferiss FJG, MacLeod KG, Willcox RR. Australia (hepatitis-associated) antigen in patients attending a venereal disease clinic. Br Med J 1973;2:455-6. 